\title{
INVESTIGATION OF CLASS 1 INTEGRONS WITH ANTIBIOTIC RESISTANCE GENES IN MULTIDRUG-RESISTANT ACINETOBACTER BAUMANNII STRAINS AND DETERMINATION OF PLANT EXTRACT EFFECTS ON MULTIDRUG-RESISTANT ISOLATES
}

\author{
AYŞEGÜL SARAL ${ }^{1}$, SEDANUR CINEMRE ${ }^{2}$, FUNDA OKUMUŞ ${ }^{2}$, ZEYNEP AKAR $^{3}$, AYŞEGÜL \\ ÇOPUR ÇIÇEK ${ }^{4}$, AZER ÖZAD DÜZGÜN ${ }^{3 *}$
}

${ }^{I}$ Department of Nutrition and Dietetics, Faculty of Health Sciences, Artvin Coruh University, Artvin, Turkey

${ }^{2}$ Department of Biotechnology, Institute of Natural Sciences, Gumushane University, Gümüşhane, Turkey

${ }^{3}$ Department of Genetics and Bioengineering, Faculty of Engineering and Natural Sciences, Gumushane University, Gümüshane, Turkey

${ }^{4}$ Recep Tayyip Erdoğan University, Faculty of Medicine, Department of Medical Microbiology, Rize, Turkey

*corresponding author: azer@gumushane.edu.tr

Manuscript received: February 2021

\begin{abstract}
This study aimed to investigate the presence of resistance genes in multidrug-resistant $A$. baumannii isolates as well as to determine the antibacterial activity of selected plant extracts against isolates. 41 strains were isolated from various clinical samples. PCR tests were performed using the primers. Methanol was used as solvent for the preparation of the plant extracts. MIC values of the plant extracts were determined by the broth microdilution method. The $b l a_{\mathrm{OXA}-23}, b l a_{\mathrm{CTX}-\mathrm{M}-1}, b l a_{\mathrm{CTX}-\mathrm{M}-2}$, $b l a_{\mathrm{GES}}$ genes and Class 1 integrons were detected in five isolated strains. The lowest MIC value $(2.25 \mathrm{mg} / \mathrm{mL}) \mathrm{was}$ determined for the Echinacea purpurea extract, while the highest MIC value (50 mg/mL) was determined for the Morus alba extract. Determination of the antibacterial effect of plants extracts used in the study against A. baumannii isolates shows the importance of screening the antibacterial activity of plants in the fight against antibiotic resistance.
\end{abstract}

\section{Rezumat}

Studiul a avut ca scop investigarea genelor de rezistență ale izolatelor de A. baumannii multirezistente, precum şi determinarea activității antibacteriene a unor extracte vegetale supra a 41 specii microbiene izolate din diferite probe clinice. Metanolul a fost folosit ca solvent de extracție. Valorile concentrației minime inhibitorii ale extractelor obținute au fost determinate prin metoda microdiluției. Genele $b l a_{\mathrm{OXA}-23}, b l a_{\mathrm{CTX}-\mathrm{M}-1}, b l a_{\mathrm{CTX}-\mathrm{M} 2}$ și $b l a_{\mathrm{GES}}$, alături de integroni din clasa 1 au fost decelate pentru 5 specii izolate. Valoarea MIC cea mai scăzută $(2,25 \mathrm{mg} / \mathrm{mL})$ a fost obținută pentru extractul din Echinaceea purpurea, în timp ce cea mai mare valoare MIC $(50 \mathrm{mg} / \mathrm{mL})$ a fost determinată pentru extractul de Morus alba. Determinarea efectului antibacterian ale extractelor vegetale împotriva izolatelor de A. baumannii arată importanța screeningului activităţii antibacteriene a plantelor în lupta împotriva rezistenței la antibiotice.

Keywords: MIC, plant extract, resistance

\section{Introduction}

A. baumannii, a Gram-negative, nosocomial pathogen resistant to most current antibiotics, has become a major challenge for modern healthcare systems [1, 2]. A. baumannii, as free-living planktonic cells or biofilms, can live at a wide range of temperature, $\mathrm{pH}$ and humidity levels. It also uses various carbon and energy sources to survive. These characteristics contribute to the persistence and spread of A. baumannii in the hospital setting [1, 3, 4]. Recently, isolates with resistance to all known antibiotics have emerged and are therefore considered to be one of the most dangerous hospital pathogens worldwide [5, 6]. A. baumannii often causes pneumonia, bacteraemia, meningitis, and wound and urinary tract infections [7].
A. baumannii isolates resistant to more than two antibiotic groups (ampicillin-sulbactam, fluoroquinolones, aminoglycosides, cephalosporins and antipseudomonal carbapenems) are defined as MDR (multidrug-resistant) $[5,6]$. The antimicrobial resistance mechanism in $A$. baumannii is divided into three categories: (i) enzymatic inactivation of antimicrobials; (ii) modification of antimicrobial targets; and (iii) reduced access to antimicrobial targets due to membrane modifications [8]. Enzymatic degradation by the $\beta$-lactamases in $A$. baumannii is the most common mechanism of $\beta$-lactam resistance [9]. The $\beta$-lactamases are divided into four groups as class $\mathrm{A}$, class B (metallo $\beta$-lactamases), class $\mathrm{C}$ and class D (oxacillinases) [9]. Class A (TEM, SHV, CTX-M1, CTX-M2, VEB), class B (VIM, IMP), class $\mathrm{C}(\mathrm{AmpC})$ and class D (OXA-23, OXA-24, 
OXA-51, OXA-58) $\beta$-lactamases have been reported worldwide in A. baumannii isolates [9]. The naturally occurring class D (OXA) carbapenemases in $A$. baumannii are the leading cause of carbapenem resistance in this microorganism [9].

Plants are capable of synthesizing secondary metabolites known as phytochemical compounds that act as plant defence mechanisms against macro and microorganisms $[5,10]$. In many cultures in Asia, Africa and some parts of America, traditional medicine has been used for decades to protect human health and also to treat various diseases [11]. Alkaloids, flavonoids, phenolics and tannins are among the most important phytochemicals used in phytotherapy $[5,12]$. In recent years, many researchers have pointed out the role of plant antibacterial activities in fighting antibiotic resistant bacteria [13]. The efficacy of plant-derived compounds in controlling various MDR pathogens, including Acinetobacter sp., is being investigated [1].

Considering these points, the present study investigated the presence of antibiotic resistance genes and Class 1 integrons in multidrug-resistant $A$. baumannii isolates from intensive care unit patients, and the effects on these isolates of methanol extracts from nine selected plants (Morus alba, Zingiber officinale, Vaccinium myrtillus, Rosa canina, Hypericum perforatum, Lycium barbarum, Aquilaria agallocha, Nigella sativa and Echinacea purpurea) were determined.

\section{Materials and Methods}

Forty-one A. baumannii strains isolated from various clinical specimens (tracheal aspirate, blood, urine, broncho-alveolar lavage) of patients hospitalized in the Rize Training and Research Hospital Intensive Care Unit, Turkey, were identified and their antibiograms were performed via the Vitek 2 Compact automated system. Isolation of DNA from the bacteria was performed using the DNA boiling method [14].

PCR tests were performed using primers of $b l a_{\mathrm{VIM}}$, $b l a_{\mathrm{NDM}}, b l a_{\mathrm{IMP}}, b l a_{\mathrm{GES}}, b l a_{\mathrm{CTXM}-1}, b l a_{\mathrm{CTXM}-2}, b l a_{\mathrm{OXA}-58}$, $b l a_{\text {OXA-23 }}, b l a_{\text {OXA-51 }}$ and Class 1 integrons [15]. The PCRs were performed in a final volume of $50 \mu \mathrm{L}$. The PCR component mix was as follows: $5 \mu \mathrm{L}$ of genomic DNA, $2 \mu \mathrm{L}$ of each primer $(20 \mathrm{pmol} / \mu \mathrm{L}), 10 \mu \mathrm{L}$ reaction buffer (Promega, Madison, WI, USA), $3 \mu \mathrm{L} 25 \mathrm{mM}$ $\mathrm{MgCl}_{2}, 4 \mu \mathrm{L}$ of each dNTP $(2.5 \mathrm{mM})$ and $1.5 \mathrm{U}$ of GoTaq ${ }^{\circledR}$ Flexi Polymerase (Promega, Madison, WI, USA). All PCR results were run on $1 \%$ agarose gel containing $0.5 \mu \mathrm{g} / \mathrm{mL}$ ethidium bromide and then visualized under ultraviolet (UV) light.

When choosing the plants to be used in the study, those which are frequently studied in the literature and widely consumed and utilized by people for various purposes were preferred. Morus alba, Zingiber officinale, Vaccinium myrtillus, Rosa canina, Hypericum perforatum, Lycium barbarum, Aquilaria agallocha, Nigella sativa and Echinacea purpurea were purchased as dry and ground from a local herbal shop. To ensure that each of the samples was completely and uniformly dried, they were oven dried and weighed at intervals for seven days. Samples $(10 \mathrm{~g})$ of each of the powdered plants were then extracted with $100 \mathrm{~mL}$ of methanol for $2 \mathrm{~h}$ using a magnetic stirrer. At the end of the process, the plant extracts were first filtered through Blue Ribbon filter paper and in the second stage, through $0.25 \mu \mathrm{M}$ filters. The clarified plant extracts were placed in glass flasks and their solvents were completely evaporated in a rotary evaporator. Their concentrations were determined by dissolving each in a specific volume of methanol. The extracts were then stored in a cool, dark environment until analysis.

The broth microdilution method was used to determine the MIC of the plant extracts against A. baumannnii isolates. Experiments were performed in triplicate using 96-well plates. Ampicillin was used as control at concentrations of $100-0.78125 \mathrm{mg} / \mathrm{mL}$. All isolates were grown on LB (Luria Bertani) medium at $37^{\circ} \mathrm{C}$. In the first 11 wells, $50 \mu \mathrm{L}$ of LB broth was placed, while, as a sterility control, $100 \mu \mathrm{L}$ of LB broth was added to the $12^{\text {th }}$ well and evaluated. In addition, the $11^{\text {th }}$ well was prepared as a growth control with $50 \mu \mathrm{L}$ LB broth $+50 \mu \mathrm{L}$ bacteria. Serial dilutions were made up to the $10^{\text {th }}$ well, starting with $50 \mu \mathrm{L}$ of the first concentration of extracts placed into the first well. Plates were incubated at $37^{\circ} \mathrm{C}$ and MIC values were determined as the concentration of the plant extract in the first well where no growth had occurred [16].

\section{Results and Discussion}

Identification and antibiograms of $41 \mathrm{~A}$. baumannii strains isolated from various clinical specimens (tracheal aspirate, blood, urine and bronchoalveolar lavage) of patients hospitalized in the Rize Training and Research Hospital Intensive Care Unit, Turkey, were studied using the Vitek 2 Compact automated system. Antibiotic resistance profiles of the 41 identified $A$. baumannii isolates are shown in Table I. The $b l a_{\text {OXA-51 }}$ gene was used to identify $A$. baumannii isolates, and this gene was detected in all of the isolates included in this study. In 38 isolates, the bla $a_{\mathrm{OXA}-23}(92.6 \%)$ class D $\beta$-lactamase gene was detected. Among the Class A $\beta$-lactamase genes, bla $_{\text {Стхм-1 }}$ was detected in 36 isolates $(87.8 \%), b a_{\mathrm{CTXM}-2}$ in 18 isolates $(43 \%)$ and $b l a_{\mathrm{GES}}$ in 1 isolate. The presence of the studied metallo $\beta$ lactamase genes ( $b l a_{\mathrm{VIM}}, b l a_{\mathrm{NDM}}$ and $\left.b l a_{\mathrm{IMP}}\right)$ and the $b l a_{\text {OXA-58 }}$ gene encoding Class D $\beta$-lactamase was not observed in any isolate. Class 1 integrons were detected in 34 isolates.

Most of the A. baumannii pathogens were isolated from the respiratory tract of hospitalized patients [9]. The clinical effect of Acinetobacter increases morbidity or mortality and A. baumannii infections are responsible for the increase in patient deaths in critically ill patients. 
Many studies have shown that $A$. baumannii has a high rate of multiple drug resistance (MDR) [9].

Table I

Antibiotic resistance rates of A. baumannii isolates

\begin{tabular}{|l|c|c|c|}
\hline \multicolumn{1}{|c|}{ Antibiotic } & S (n/\%) & I (n/\%) & R (n/\%) \\
\hline PIP & - & - & $100 \%(41)$ \\
\hline SXT & $13.51 \%(6)$ & $2.7 \%(2)$ & $83.78 \%(35)$ \\
\hline CAZ & - & $2.7 \%(2)$ & $97.3 \%(40)$ \\
\hline IMP & $2.7 \%(2)$ & - & $97.3 \%(40)$ \\
\hline MEM & $2.7 \%(2)$ & - & $97.3 \%(40)$ \\
\hline GN & $24.32 \%(10)$ & $13.51 \%(6)$ & $62.16 \%(25)$ \\
\hline NET & $27.03 \%(11)$ & $10.81 \%(5)$ & $62.16 \%(25)$ \\
\hline TOB & $32.43 \%(13)$ & - & $67.57 \%(27)$ \\
\hline TIG (N = 35) & $20 \%(8)$ & $80 \%(30)$ & - \\
\hline TZP & - & $2.7 \%(2)$ & $97.3 \%(40)$ \\
\hline COL & $97.3 \%(40)$ & $2.7 \%(2)$ & - \\
\hline LEV & - & - & $100.0 \%(41)$ \\
\hline
\end{tabular}

PIP: Piperacillin, SXT: Trimethoprim-sulfamethoxazole, CAZ: Ceftazidime, IMP: Imipenem, MEM: Meropenem, GN: Gentamicin, NET: Netilmicin, TOB: Tobramycin, TIG: Tigecycline, TZP: Piperacillin-tazobactam, COL: Colistin, LEV: Levofloxacin

Extended-spectrum $\beta$-lactamases (ESBLs) are plasmidmediated and produced by Gram-negative bacilli that provide resistance to penicillin, cephalosporin and monobactams. These ESBLs are commonly found worldwide in Enterobacteriaceae, Pseudomonas aeruginosa and $A$. baumannii. Included in ESBL members are TEM-, SHV-, or CTX-M-type $\beta$-lactamases. The CTX-M-type $\beta$-lactamases are divided into five groups according to amino acid sequence: CTX-M-1, CTX-M-2, CTX-M-8, CTX-M-9 and CTX-M-25 [17]. The CTX-M $\beta$-lactamases produced by $A$. baumannii strains are plasmid-mediated and therefore find a wide distribution in hospitals. In this study, the PCR method was used to detect the presence of CTX-M-1 and CTX-M-2 $\beta$-lactamase encoding genes in the isolates. It was determined that 36 strains $(87.8 \%)$ tested positive for $b l a_{\mathrm{CTX}-\mathrm{M}-1}$ and 18 isolates (43\%) tested positive for $b l a_{\mathrm{CTX}-\mathrm{M}-2}$.
In a multicentre study conducted in 2016 in Turkey, 443 isolates of A. baumannii were studied, and CTXM-1 was identified in 63 isolates and CTX-M-2 in 42 isolates [18]. The presence of CTX-M-1 and CTXM-2 $\beta$-lactamases in $96 \mathrm{~A}$. baumannii isolates from Turkey was investigated and no positive results were obtained for the isolates [19]. In the same study, the presence of OXA-23 and OXA-51 class D $\beta$-lactamases was detected in all strains [19].

Similar results were obtained in this study. The presence of OXA-51 $\beta$-lactamase was detected in all 41 isolates and OXA-23 $\beta$-lactamase was found in 38 isolates. The bla $a_{\mathrm{OXA}-51}$ gene is naturally found on the A. baumannii chromosome. The $b l a_{\mathrm{OXA}-23}$ is plasmid in origin and is found in isolates in many countries around the world.

The presence of the bla $a_{\mathrm{OXA}-23}$ gene in clinical isolates of A.baumannii from Turkey varies from 31 to $92 \%$ [19]. In our study, the presence of OXA-40 and OXA58 class $\mathrm{D} \beta$-lactamases was not observed in any of the isolates. Of the class A carbapenemases, the GEStype $\beta$-lactamase encoding $b l a_{\mathrm{GES}}$ was detected in only one isolate, whereas none of the class-B $\beta$-lactamase encoding genes $\left(b l a_{\mathrm{VIM}}\right.$, bla $_{\mathrm{NDM}}$, bla $\left._{\mathrm{IMP}}\right)$ were found. Integrons are genetic elements that recognize and capture mobile gene cassettes carrying antimicrobial drug resistance determinants. Class 1 integrons are associated with multidrug-resistant pathogens. Class 1 integrons are frequently found in A. baumannii [20]. In this study, Class 1 integrons were identified in 34 of the 41 multidrug-resistant $A$. baumannii isolates. The MIC values of nine plant extracts against six $A$. baumannii isolates with different antibiotic resistance phenotypes and genes were determined. The codes of the isolates, the resistance genes they carry and the MIC values of the plant extracts against these isolates are given in Table II.

Table II

MIC values of plant extracts against multidrug-resistant isolates

\begin{tabular}{|c|c|c|c|c|c|c|c|c|c|c|}
\hline & & \multicolumn{9}{|c|}{ Plant Extracts Used in the Study } \\
\hline $\begin{array}{l}\text { Bacteria } \\
\text { codes }\end{array}$ & $\begin{array}{c}\text { Resistance genes } \\
\text { carried by } \\
\text { isolates }\end{array}$ & \begin{tabular}{|l|} 
Aquilaria \\
agallocha
\end{tabular} & $\begin{array}{c}\text { Nigella } \\
\text { sativa }\end{array}$ & $\begin{array}{c}\text { Lycium } \\
\text { barbarum }\end{array}$ & $\begin{array}{l}\text { Hypericum } \\
\text { perforatum }\end{array}$ & $\begin{array}{c}\text { Zingiber } \\
\text { officinale }\end{array}$ & $\begin{array}{c}\text { Morus } \\
\text { alba }\end{array}$ & $\begin{array}{c}\text { Rosa } \\
\text { canina }\end{array}$ & \begin{tabular}{|c|} 
Vaccinium \\
myrtillus
\end{tabular} & $\begin{array}{l}\text { Echinacea } \\
\text { purpurea }\end{array}$ \\
\hline AB38 & \begin{tabular}{|l|} 
Class 1 integron, \\
OXA-51, OXA-23 \\
\end{tabular} & - & $\begin{array}{c}20 \\
g / m L \\
\end{array}$ & $\begin{array}{c}35 \\
\mathrm{mg} / \mathrm{mL}\end{array}$ & $\begin{array}{c}10 \\
\mathrm{mg} / \mathrm{mL}\end{array}$ & $\begin{array}{c}30 \\
\mathrm{mg} / \mathrm{mL}\end{array}$ & $\begin{array}{c}12.5 \\
\mathrm{mg} / \mathrm{mL}\end{array}$ & $\begin{array}{c}35 \\
\mathrm{mg} / \mathrm{mL} \\
\end{array}$ & - & $\begin{array}{c}2.75 \\
\mathrm{mg} / \mathrm{mL}\end{array}$ \\
\hline AB43 & $\begin{array}{l}\text { Class } 1 \text { integron, } \\
\text { OXA-51, OXA-23, } \\
\text { CTX-M1, CTX-M2 }\end{array}$ & - & $\begin{array}{c}20 \\
g / m L\end{array}$ & $\begin{array}{c}35 \\
\mathrm{mg} / \mathrm{mL}\end{array}$ & $\begin{array}{c}10 \\
\mathrm{mg} / \mathrm{mL}\end{array}$ & - & $\begin{array}{c}50 \\
\mathrm{mg} / \mathrm{mL}\end{array}$ & - & - & $\begin{array}{c}2.25 \\
\mathrm{mg} / \mathrm{mL}\end{array}$ \\
\hline AB45 & \begin{tabular}{|l|} 
Class 1 integron, \\
OXA-51, OXA-23, \\
CTX-M1, CTX-M2 \\
\end{tabular} & - & $\begin{array}{c}20 \\
\mathrm{~g} / \mathrm{mL}\end{array}$ & $\begin{array}{c}17.5 \\
\mathrm{mg} / \mathrm{mL}\end{array}$ & $\begin{array}{c}10 \\
\mathrm{mg} / \mathrm{mL}\end{array}$ & $\begin{array}{c}30 \\
\mathrm{mg} / \mathrm{mL}\end{array}$ & $\begin{array}{c}25 \\
\mathrm{mg} / \mathrm{mL}\end{array}$ & - & - & $\begin{array}{c}2.75 \\
\mathrm{mg} / \mathrm{mL}\end{array}$ \\
\hline AB46 & $\begin{array}{c}\text { OXA-51, OXA-23, } \\
\text { CTX-M2 }\end{array}$ & - & $\begin{array}{c}20 \\
\mathrm{mg} / \mathrm{mL}\end{array}$ & $\begin{array}{c}35 \\
\mathrm{mg} / \mathrm{mL}\end{array}$ & - & $\begin{array}{c}15 \\
\mathrm{mg} / \mathrm{mL}\end{array}$ & - & - & - & $\begin{array}{c}2.25 \\
\mathrm{mg} / \mathrm{mL}\end{array}$ \\
\hline AB59 & $\begin{array}{c}\text { OXA-51, OXA-23, } \\
\text { CTX-M1 }\end{array}$ & - & $\begin{array}{c}20 \\
\mathrm{~g} / \mathrm{mL}\end{array}$ & $\begin{array}{c}35 \\
\mathrm{mg} / \mathrm{mL}\end{array}$ & - & $\begin{array}{c}15 \\
\mathrm{mg} / \mathrm{mL}\end{array}$ & - & - & - & - \\
\hline AB69 & $\begin{array}{l}\text { Class } 1 \text { integron, } \\
\text { OXA-51, CTX-M1 }\end{array}$ & - & $\begin{array}{c}20 \\
\mathrm{mg} / \mathrm{mL}\end{array}$ & $\begin{array}{c}17.5 \\
\mathrm{mg} / \mathrm{mL}\end{array}$ & - & - & - & - & - & - \\
\hline
\end{tabular}


Among the plant extracts, Echinacea purpurea was found to have the lowest MIC against the multidrugresistant A. baumannii isolates. The MIC of Echinacea purpurea methanol extract was $2.75 \mathrm{mg} / \mathrm{mL}$ for $\mathrm{AB} 38$ and $\mathrm{AB} 45$, and $2.25 \mathrm{mg} / \mathrm{mL}$ for $\mathrm{AB} 43$ and $\mathrm{AB} 46$.

The MIC of Nigella sativa methanol extract was 20 $\mathrm{mg} / \mathrm{mL}$ against all studied clinical isolates. It was found that the MIC of Hypericum perforatum methanol extract for $\mathrm{AB} 38, \mathrm{AB} 43$ and $\mathrm{AB} 45$ was $10 \mathrm{mg} / \mathrm{mL}$, while this extract did not inhibit the growth of $\mathrm{AB} 46$, AB59 or AB69 at the tested concentrations. The MIC value of Lycium barbarum methanol extract against isolates AB38, AB43, AB46 and AB59 was $35 \mathrm{mg} / \mathrm{mL}$ and $17.5 \mathrm{mg} / \mathrm{mL}$ against $\mathrm{AB} 45$ and $\mathrm{AB} 69$.

The MIC of Zingiber officinale methanol extract was found to be $30 \mathrm{mg} / \mathrm{mL}$ for $\mathrm{AB} 38$ and $\mathrm{AB} 45$ and 15 $\mathrm{mg} / \mathrm{mL}$ for $\mathrm{AB} 46$ and $\mathrm{AB} 59$, whereas it did not inhibit the growth of $\mathrm{AB} 43$ or $\mathrm{AB} 69$ isolates at the tested concentrations. The MIC values of the methanol extract of Morus alba against AB38, AB43 and AB45 isolates were determined as $12.5 \mathrm{mg} / \mathrm{mL}, 50 \mathrm{mg} / \mathrm{mL}$ and $25 \mathrm{mg} / \mathrm{mL}$, respectively.

The Rosa canina methanol extract inhibited the growth of AB38 alone among the studied isolates. It was observed that the methanol extracts of Aquilania agalloeha and Vaccinium myrtillus exhibited no antimicrobial activity against the multidrug-resistant $A$. baumannii clinical isolates (AB38, AB43, AB45, AB46, AB59 and AB69) at the concentrations tested.

Since no new antibiotics have been developed against carbapenem-resistant $A$. baumannii isolates, the antimicrobial activity of plant-derived substances used in traditional medicine has been of particular interest [21]. Secondary metabolites are responsible for the antimicrobial activities of plants. Various plant active compounds with effective activity against $A$. baumannii have been identified worldwide [21].

In the present study, the MIC values of nine different plant methanol extracts were determined against MDR A. baumannii clinical isolates having six different resistance gene patterns. In one study, antimicrobial activity of methanol, acetone and chloroform extracts of Zingiber officinale against MDR A. baumannii was investigated [13]. According to the results, the chloroform plant extract had the highest activity against MDR A. baumannii, with a MIC value of $25 \mathrm{mg} / \mathrm{mL}$. In our study, the methanol extract of Zingiber officinale was found to have a MIC of $15 \mathrm{mg} / \mathrm{mL}$ against MDR A. baumannii. In a study conducted by Miyasaki et $a l$., the MIC value of Rosa rugosa extract against $A$. baumannii isolates was determined as $50 \mu \mathrm{g} / \mathrm{mL}[21$, 22]. In this study, the antimicrobial activity of Rosa canina methanol extract on A. baumannii isolates was investigated and the MIC value was found to be 35 $\mathrm{mg} / \mathrm{mL}$. Javadian et al. examined the antimicrobial activity of Peganum harmala and Heracleum persicum against $A$. baumannii and suggested that extracts obtained from both of these might be useful for treating bacterial infections [23]. The antibacterial activity of Pinus pinaster bark extract against MDR A. baumannii isolates was investigated in another study that found the extract could be useful in the fight against resistant bacteria [24]. In another study, the antibacterial activities of Oliveria decumbens, Pelargonium graveolens, Eugenia caryophyllata, Ziziphora tenuir and Trachyspermum copticum oils were evaluated against 32 clinical isolates of A. baumannii. Essential oils of $O$. decumbens, $E$. caryophyllata and T. copticum were found to have the best antibacterial activity against the clinical isolates of A. baumannii [25]. Zhang et al. investigated the antibacterial activity of Mentha arvensis ethanol extract on MDR A. baumannii isolates and found this extract to be an effective antibacterial against the isolates [26]. This study investigated the antibacterial effect of methanol extracts of nine different medicinal plants on MDR A. baumannii isolates. According to the results, the growth of the isolates harbouring different antibiotic resistance genes was inhibited by different plant extracts.

\section{Conclusions}

The emergence of resistant strains of bacterial pathogens has resulted in limited treatment options. Traditionally, plants play an important role in the treatment of diseases and have secondary metabolites that are reported to be potentially active against a variety of bacteria. Therefore, plants can be used as a resource in the search for alternative medicines to replace existing antibiotics.

\section{Conflict of interest}

The authors declare no conflict of interest.

\section{References}

1. Kon K, Controlling Bacterial Antibiotic Resistance Using Plant-Derived Antimicrobials. In: Upadhyay A, Karumathil DP, Upadhyaya I, Bhattaram V, Venkitanarayanan K, editors. Antibiotic Resistance Mechanisms and New Antimicrobial Approaches. $1^{\text {st }}$ ed. Kharkiv, Ukraine: Academic Press; 2016; 205-215.

2. Sacha P, Wieczorek P, Ojdana D, Czaban S, Klosowska W, Jurczak A, Tryniszewska E, Susceptibility, phenotypes of resistance, and extended-spectrum $\beta$-lactamases in Acinetobacter baumannii strains. Folia Histochem Cytobiol., 2012; 50(1): 46-51.

3. Espinal P, Marti S, Vila J, Effect of biofilm formation on the survival of Acinetobacter baumannii on dry surfaces. J Hosp Infect., 2012; 80(1): 56-60.

4. Almaghrabi MK, Joseph MRP, Assiry MM, Hamid ME, Multidrug-Resistant Acinetobacter baumannii: An Emerging Health Threat in Aseer Region, Kingdom of Saudi Arabia. Can J Infect Dis Med Microbiol., 2018; 2018: 9182747: 1-4.

5. Abdallah EM, Antibacterial activity of Hibiscus sabdariffa $\mathrm{L}$. calyces against hospital isolates of multidrug resistant Acinetobacter baumannii. J Acute Dis., 2016; 5(6): 512-516. 
6. Peleg AY, Seifert H, Paterson DL, Acinetobacter baumannii: emergence of a successful pathogen. Clin Microbiol Rev., 2008; 21(3): 538-582.

7. Pasanen T, Koskela S, Mero S, Tarkka E, Tissari P, Vaara M, Kirveskari J, Rapid molecular characterization of Acinetobacter baumannii clones with rep-PCR and evaluation of carbapenemase genes by new multiplex PCR in Hospital District of Helsinki and Uusimaa. PLoS One, 2014; 9(1): e85854: 1-8.

8. Manchanda V, Sanchaita S, Singh N, Multi drug resistant Acinetobacter. J Glob Infect Dis., 2010; 2(3): 291-304.

9. Almasaudi SB, Acinetobacter spp. as nosocomial pathogens: Epidemiology and resistance features. Saudi J Biol Sci., 2018; 25(3): 586-596.

10. Manandhar S, Luitel S, Dahal RK, In Vitro Antimicrobial Activity of Some Medicinal Plants against Human Pathogenic Bacteria. J Trop Med., 2019; 2: 2019: 1895340: 1-5.

11. Verma VC, Gond SK, Kumar A, Mishra A, Kharwar RN, Gange AC, Endophytic actinomycetes from Azadirachta indica A. Juss.: isolation, diversity, and anti-microbial activity. Microb Ecol., 2009; 57(4): 749-756.

12. Purkayastha S, Dahiya P, Phytochemical analysis and antibacterial efficacy of babchi oil (Psoralea corylifolia) against multi-drug resistant clinical isolates. Int Conf Biosci Biochem Bioinf., 2012; 31: 64-68.

13. Yeganeh SH, Doost SRH, Goudarzi M, Antimicrobial effects of Zingiber officinale extracts against multidrug resistant Acinetobacter baumannii clinical isolates recovered from hospitalized patients in ICU. J Paramed Sci., 2018; 9(3): 42-50.

14. Copur Cicek A, Saral A, Ozad Duzgun A, Yasar E, Cizmeci Z, Ozlem Balci P, Sari F, Firat M, Altintop YA, Ak S, Caliskan A, Yildiz N, Sancaktar M, Esra Budak E, Erturk A, Birol Ozgumus O, Sandalli C, Nationwide study of Escherichia coli producing extendedspectrum $\beta$-lactamases TEM, SHV and CTX-M in Turkey. J Antibiot (Tokyo), 2013; 66(11): 647-650.

15. Cicek AC, Saral A, Iraz M, Ceylan A, Duzgun AO, Peleg AY, Sandalli C, OXA- and GES-type $\beta$ lactamases predominate in extensively drug-resistant Acinetobacter baumannii isolates from a Turkish University Hospital. Clin Microbiol Infect., 2014; 20(5): 410-415.

16. Chuah EL, Zakaria ZA, Suhaili Z, Abu Bakar S, Desa MNM, Antimicrobial Activities of Plant Extracts against Methicillin-Susceptible and Methicillin-Resistant Staphylococcus aureus. J Microbiol Res., 2014; 4(1): 6-13.

17. Alyamani EJ, Khiyami MA, Booq RY, Alnafjan BM, Altammami MA, Bahwerth FS, Molecular characterization of extended-spectrum beta-lactamases (ESBLs) produced by clinical isolates of Acinetobacter baumannii in Saudi Arabia. Ann Clin Microbiol Antimicrob., 2015; 20(14): 38: 1-9.

18. Beriş FŞ, Budak EE, Gülek D, Uzun A, Çizmeci Z, Mengeloğlu FZ, Direkel Ş, Çetinkol Y, Ay Altıntop Y, Iraz M, Dal T, Say Coşkun SU, Balcı PÖ, Kayman T, Çalışkan A, Yazıcı Y, Tosun İ, Ertürk A, Çopur Çiçek A, Investigation of the frequency and distribution of beta-lactamase genes in the clinical isolates of Acinetobacter baumannii collected from different regions of Turkey: a multicenter study. Mikrobiyol Bul., 2016; 50(4): 511-521.

19. Say Coskun US, Caliskan E, Cicek AC, Turumtay H, Sandalli C, $\beta$-lactamase genes in carbapenem resistance Acinetobacter baumannii isolates from a Turkish university hospital. J Infect Dev Ctries., 2019; 13(1): 50-55.

20. Eftekhar F, Altayar F, Khidaei H, Plasmid-Mediated Class 1 and 2 Integron Carriage in Drug-Resistant Nosocomial Isolates of Acinetobacter baumannii. Arch Clin Infect Dis., 2018; 13(1): e57813: 1-5.

21. Tiwari V, Roy R, Tiwari M, Antimicrobial active herbal compounds against Acinetobacter baumannii and other pathogens. Front Microbiol., 2015; 18(6): 618: 1-11.

22. Miyasaki Y, Rabenstein JD, Rhea J, Crouch ML, Mocek UM, Kittell PE, Morgan MA, Nichols WS, Van Benschoten MM, Hardy WD, Liu GY, Isolation and characterization of antimicrobial compounds in plant extracts against multidrug-resistant Acinetobacter baumannii. PLoS ONE, 2013; 22: 8(4): e61594: 1-8.

23. Javadian F, Saeidi S, Jahani S, Antimicrobial Activity of Peganum harmala and Heracleum persicum against Acinetobacter baumannii. Int J Infect., 2016; 3(1): e33554: 1-4.

24. Ćurković-Perica M, Hrenović J, Kugler N, GoićBarišić I, Tkalec M, Antibacterial Activity of Pinus pinaster bark extract and its components against multidrug-resistant clinical isolates of Acinetobacter baumannii. Croat Chem Acta, 2015; 88(2): 133-137.

25. Mahboubi M, Kazempour N, Taghizadeh M, The antibacterial activity of some essential oils against clinical isolates of Acinetobacter baumannii. Songklanakarin J Sci Technol., 2014; 36(5): 513-519.

26. Zhang L, Xu S, Liang W, Mei J, Di Y, Lan H, Yang Y, Wang W, Luo Y, Wang H, Antibacterial activity and mode of action of Mentha arvensis ethanol extract against multidrug-resistant Acinetobacter baumannii. Trop J Pharm Res., 2015; 14(11): 2099-2106. 